\title{
Effect of Mechanical Properties on Carbon Nanotubes, Nanoclays Reinforced Epoxy Carbon Fabric Composite Pipes
}

\author{
Bülent Karaoğlu ${ }^{1 *}$, Hüseyin Arıkan ${ }^{2}$, Mehmet Kayrıc1 ${ }^{3}$ \\ ${ }^{1^{*}}$ Necmettin Erbakan University, The Graduate School of Natural and Applied Science, Departmant of Mechanical Engineering, Konya, Turkey, (ORCID: 0000-0002- \\ 7872-4071), bulentkaraoglu2@gmail.com \\ ${ }^{2}$ Necmettin Erbakan University, Faculty of Seydişehir Ahmet Cengiz Engineering, Departmant of Mechanical Engineering, Konya, Turkey, (ORCID: 0000-0003-1266- \\ 4982), harikan@erbakan.edu.tr \\ 3 Necmettin Erbakan University, Faculty of Seydişehir Ahmet Cengiz Engineering, Departmant of Mechanical Engineering, Konya, Turkey, (ORCID: 0000-0003- \\ 1178-5168), mkayrici@erbakan.edu.tr
}

(1st International Conference on Applied Engineering and Natural Sciences ICAENS 2021, November 1-3, 2021)

(DOI: 10.31590/ejosat.995135)

ATIF/REFERENCE: Karaoğlu, B., Arıkan, H. \& Kayrıcı, M. (2021). Effect of Mechanical Properties on Carbon Nanotubes, Nanoclays Reinforced Epoxy Carbon Fabric Composite Pipes. European Journal of Science and Technology, (28), $198-206$.

\begin{abstract}
Generally, the nanofillers increase the mechanical and impact behaviors of fiber reinforced polymer based composites. However, the effects of the hybridization of nanofillers and their reasons over the nano scale damage mechanisms have not been adequately studied for fabric reinforced composites. The low velocity impact responses and mechanical properties of carbon nanotubes, nanoclays particles reinforced epoxy carbon fabric composite pipes have been evaluated in this study. Carbon fabric composite pipes have been prepared with 1 , and $3 \mathrm{wt} \%$ of carbon nanotube and 1,and $3 \mathrm{wt} \%$ of nanoclay particles and unfilled nanofillers, using hand lay-up technique. Mechanical properties of low velocity impact for carbon nanotubes (MWCNT), nanoclays particles reinforced epoxy carbon fabric composite pipes have been obtained as a function of content of nanofillers particles. The low-velocity impact tests applied on composite pipes for energy levels $5 \mathrm{~J}, 10 \mathrm{~J}$, and $15 \mathrm{~J}$ according to in accordance with ASTM D7136 / D7136 M-12 standards. It was observed that carbon nanotubes (MWCNT) and nanoclay nanofillers addition to Carbon Fabric/Epoxy for 5J, $10 \mathrm{~J}$ and $15 \mathrm{~J}$ showed maximum force, absorbed energy and the lowest displacements and rebound energy. MWCNTs and nanoclays nanohybrid addition to Carbon Fabric/Epoxy improved higher low velocity impact responses than none nanofillers addition. The specimens of unfilled nanofillers Carbon Fabric/Epoxy composites showed the lowest maximum force, highest displacements and rebound energy. The results show that the mechanical properties are found to increase substantially with increasing carbon nanotube (MWCNT) and nanoclays particles with Carbon Fabric/Epoxy composite pipes.
\end{abstract}

Keywords: Composite pipe, Fabric, Epoxy, Carbon nanotubes (MWCNT), Nanoclay, Fabrication, Impact, Damage, ASTM.

\section{Karbon Nanotüp ve Nanokil Takviyesinin Epoksi Karbon Kumaş Kompozit Boruların Mekanik Özelliklerine Etkisinin İncelenmesi}

$\ddot{O} \mathbf{z}$

Genel olarak nano dolgular, fiber takviyeli polimer esaslı kompozitlerin mekanik ve darbe davranışlarını arttırır. Bununla birlikte, nano dolgu maddelerinin hibridizasyona etkileri ve bunların nano ölçekli hasar mekanizmaları üzerindeki nedenleri, kumaş takviyeli kompozitler için yeterince çalışılmamıştır. Bu çalışmada karbon nanotüpler, nanokil partikülleri takviyeli epoksi karbon kumaş kompozit boruların düşük hızlı darbe tepkileri ve mekanik özellikleri değerlendirilmiştir. Karbon kumaş kompozit borular, ağırlıkça $\% 1$ ve 3 karbon nanotüp ve ağırlıkça \%1 ve 3 nanokil parçacıkları ve nano madde dolgusuz olarak, elle yatırma tekniği kullanılarak

* Corresponding Author: bulentkaraoglu2@gmail.com 
hazırlanmıştır. Karbon nanotüp (MWCNT), nanokil takviyeli epoksi karbon kumaş kompozit borular için düşük hız darbe etkileri ve mekanik özellikleri, nanodolgu partiküllerin içeriğinin bir fonksiyonu olarak elde edilmiştir. ASTM D7136 / D7136 M-12 standartlarına göre $5 \mathrm{~J}, 10 \mathrm{~J}$ ve $15 \mathrm{~J}$ enerji seviyeleri için kompozit borulara düşük hızlı darbe testleri uygulanmıştır. $5 \mathrm{~J}, 10 \mathrm{~J}$ ve $15 \mathrm{~J}$ için Karbon Kumaş/Epoksi'ye ilave edilen karbon nanotüpler (MWCNT) ve nanokil nanodolgularının, maksimum kuvvet, emilen enerji ve en düşük yer değiştirme ve geri tepme enerjisi gösterdiği gözlendi. Karbon Kumaş/Epoksi'ye ,MWCNT ve nanokil gibi nanohibrit ilavesi ise nano dolgu maddesi ilavesi olmayandan, daha yüksek düşük hızlı darbe tepkileri oluşturdu. Nano dolgu maddeleri eklenmemiş Karbon Kumaş/Epoksi kompozit örnekleri, en düşük maksimum kuvvet, en yüksek yer değiş̧irmeleri ve geri tepme enerjisini gösterdi. Sonuçlar, Karbon Kumaş/Epoksi kompozit borular ile karbon nanotüp (MWCNT) ve nanokil parçacıklarının artmasıyla mekanik özelliklerin önemli ölçüde arttığını göstermektedir.

Anahtar Kelimeler: Kompozit boru, Kumaş, Epoksi, Karbon nanotüpler (MWCNT), Nanokil, İmalat, Darbe, Hasar, ASTM.

\section{Introduction}

Today's world, human need new materials for using in their lifelong. Composite materials have been used by the people of earlier civilization since many centuries. One of good example include the preparation of bricks for building construction using straw and mud [1 - 5]. Engineering materials design with two or more parts are produces composites materials in macro scales [6 - 9]. Composite materials combine matrix materials with reinforced parts that holding the perfect physical or chemical properties of each component [10].

Fiber reinforced polymer (FRP) composite materials are being considered for replacing the metallic components in aviation, naval and automotive industries. Compared to metal, FRP composites have low density, higher specific strength and stiffness, higher corrosion resistance and improved fatigue performance.

Performance of these FRP's under various loading condition; such as axial, torsional and impact loading are very crucial for the design of structural components. Mechanical properties of fiber reinforced polymer composites depend on the fiber, matrix and the interface between them. Researchers have been investigating various organic and inorganic nanoparticles as reinforcement of composites to improve the mechanical properties and thermal stability [11,12].Significant development in the use of nanoparticles for modification of epoxy matrix has led to improved mechanical properties of the FRP composites. The advantages of nanoparticles are their high specific strength and modulus along with low density. As a result, very low percentage of nanoparticles addition can enhance the properties of composites significantly [13 - 15].

Composite carbon reinforced pipes (CRP) include nano fillers that have good mechanical properties for engineering application compared to metals materials. Some of nano fillers are carbon nanotube and nanoclays. Carbon nanotubes (CNT) are predominately effective in mechanical properties such as tensile strength and Young's modulus. The tensile strength of CNTs is due to the covalent sp 2 bond between the neighbouring existing carbon atoms. Due to the $\mathrm{C}-\mathrm{C}$ bonds in the lattice, CNT's are expected to achieve high Young's modulus in the axial direction. Young's modulus of MWCNT's (multiwall CNT) is $1.2 \mathrm{TPa}$. Clay deposits composed of clay minerals (phyllosilicate minerals). Clay is a naturally occurring mineral composed primarily of fine grained minerals. These minerals shows plasticity owing to variable water content and on drying or fired can be hardened. Nanoclays is the good example of naturally occurring nanomaterials which are generally used for a clay mineral having a phyllosilicate or sheet structure with a thickness of about $1 \mathrm{~nm}$ and surfaces about $50-150 \mathrm{~nm}$ in one dimension. Nanoclays are thus the general term for the layered mineral silicates nanoparticles having high aspect ratio. Depending on morphology of nano particles and chemical composition nanoclays are arranged into various classes such as illite, halloysite, bentonite, kaolinite, montmorillonite, hectorite and chlorite [16 - 19]. These days the growing concern towards the utilization of renewable materials as filler in the matrix highlights greatly the importance of layered silicates clay minerals as nano filler owing to its availability and versatility [20 - 24]. Toyota research group in the early 90 s, proclaimed the first use of nanoclays reinforcement in the manufacturing of nylon-6-based nanoclay composites. According as the process conditions and polymer/nanofillers bonding the layered silicates dispersed into the polymer matrix in different states of intercalation and/or exfoliation. Polymer nanoclay composites comprice the interaction of polymer matrix with the nano-plates of clay, and their formed by the dispersion of low weight percentages of nanoclay into polymers. Nanoclay reinforced polymer composites and their laminates have perfect properties including enhanced physical like optical, dielectric, permeability ,transparency and lower shrinkage, and thermal like decomposition temperature, flammability, coefficient of thermal expansion and higher thermal stability. Their have mechanical properties like tensile toughness, tensile strength and tensile modulus, even at a very low filler loading with respect to pure polymers [25 - 29]. Polymer nanoclay composites are one of the most hopeful alternatives to steel and wood based polymer composite, firstly developed for the aerospace industry [30,31].

Normally, composite pipe made by fiber winding. Although, our composite pipes are making by carbon fabric wound that fast and economically. This work, in low-speed impact tests, with the increase of impact energy, the maximum contact force, displacement amount and contact time between the striker and the sample increase on the CRP composite pipe sample. The contact force-displacement and energy-impact energy variations obtained from the impact experiments show that the amount of energy absorbed by the sample increases with the increase of the impact energy when the ratio of the amount of energy absorbed to the impact energy is examined. 


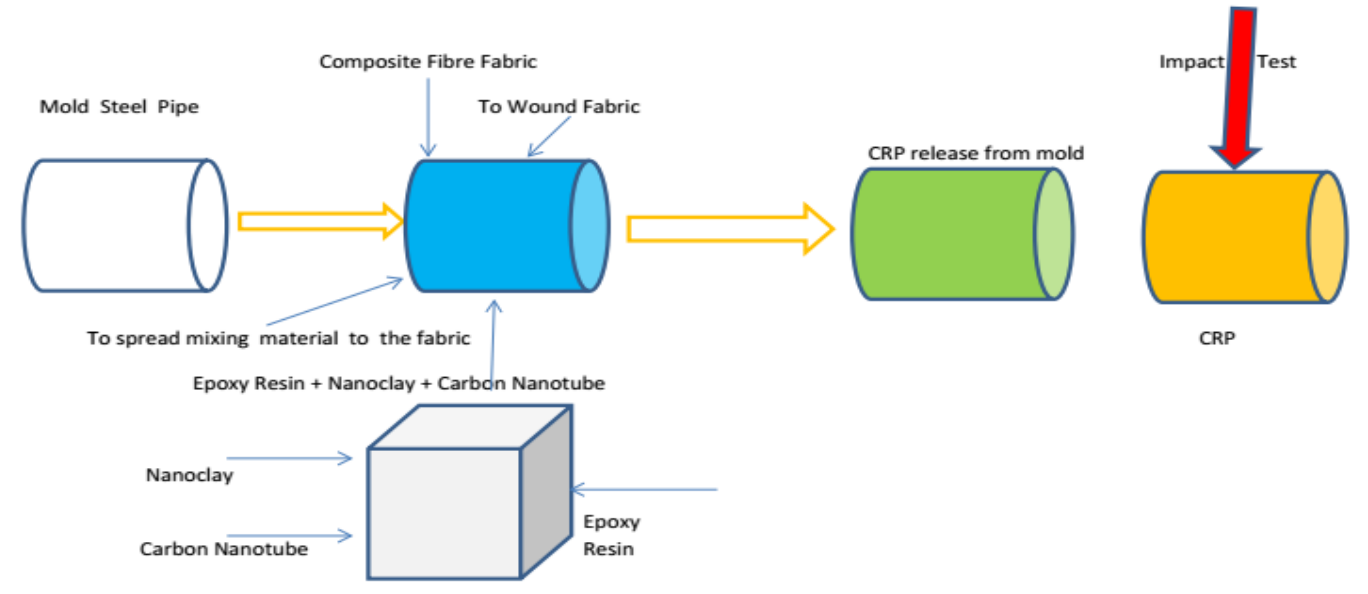

Figure 1 The simple flowsheet of composite reinforced pipe (CRP) manufacture.

\section{Material and Method}

\subsection{Experimental Procedure}

\subsubsection{Raw Materials:}

Mold : Steel with shine outer surface, length $1300 \mathrm{~mm}$, diameter $72 \mathrm{~mm}$, thickness $4 \mathrm{~mm}$.

Nanoclay : White, Montmorillonite type , 38 - $40 \mathrm{~A}^{\circ}$, Angstrom, between two layers.

Nanotube : Carbon MWNT (multiwall nanotube), Purity ( $>95 \%$ carbon nano tube), Diameter 10-20 nm.

Carbon Texture: Carbon fiber fabric, bi-axial $+45 /-45$ degrees, $300 \mathrm{gr} / \mathrm{m}^{2}$, Tensile strenght: $3800 \mathrm{MPa}$, Modulus of elasticity: $240 \mathrm{GPa}$, Density: $1.79 \mathrm{~g} / \mathrm{cm}^{3}$.

Epoxy Resin : Hexion LR160, hardener LH160, weight ratio 100:25. Density: $1.18-1.20 \mathrm{~g} / \mathrm{cm}^{3}$, Flexural strength: $110-140$ $\mathrm{N} / \mathrm{mm}^{2}$, Modulus of elasticity: $3.2-3.5 \mathrm{kN} / \mathrm{mm}^{2}$, Tensile strength: 70-80 N/mm ${ }^{2}$, Compressive strength: $80-100 \mathrm{~N} / \mathrm{mm}^{2}$, Impact strength: $40-50 \mathrm{KJ} / \mathrm{m}^{2}$.

\subsection{Fabrication}

Composite pipes were manufactured taylor-made by hand lay-up method that based on carbon fabric wound by me in the composite laboratory of Necmettin Erbakan University Ahmet Cengiz Engineering Faculty, Seydisehir, Konya. The simple flowsheet of composite reinforced manufacture is view in Figure 1. Composite pipe manufacture need a mold.The mold is preparing from steel with shine (length $1300 \mathrm{~mm}$, diameter 72 $\mathrm{mm}$, thickness $4 \mathrm{~mm}$ ) in Figure 2.

Composite pipes have four different ingredients which based on same epoxy resins include hardener (600 gr epoxy, 150 gr hardener) and carbon fiber texture $(1.5 \mathrm{~m})$.

The first pipe has no filler adding, the second pipe on based mass weight percent resin has 6 gr,or $1 \mathrm{wt} \% \mathrm{CNT}$ with 6 gr, or 1 $\mathrm{wt} \%$ nanoclay and the third pipe has $6 \mathrm{gr}$, or $1 \mathrm{wt} \% \mathrm{CNT}$ with 18 $\mathrm{gr}$, or $3 \mathrm{wt} \%$ nanoclay, and last the fourth pipe has $18 \mathrm{gr}$, or 3 wt $\%$ CNT with $6 \mathrm{gr}$, or $1 \mathrm{wt} \%$ nanoclay.
The first pipe has no filler adding, the second pipe on based mass weight percent resin has 6 gr,or $1 \mathrm{wt} \%$ CNT with 6 gr, or 1 $\mathrm{wt} \%$ nanoclay and the third pipe has $6 \mathrm{gr}$, or $1 \mathrm{wt} \%$ CNT with 18 gr, or $3 \mathrm{wt} \%$ nanoclay , and last the fourth pipe has $18 \mathrm{gr}$, or 3 wt $\%$ CNT with $6 \mathrm{gr}$, or $1 \mathrm{wt} \%$ nanoclay.

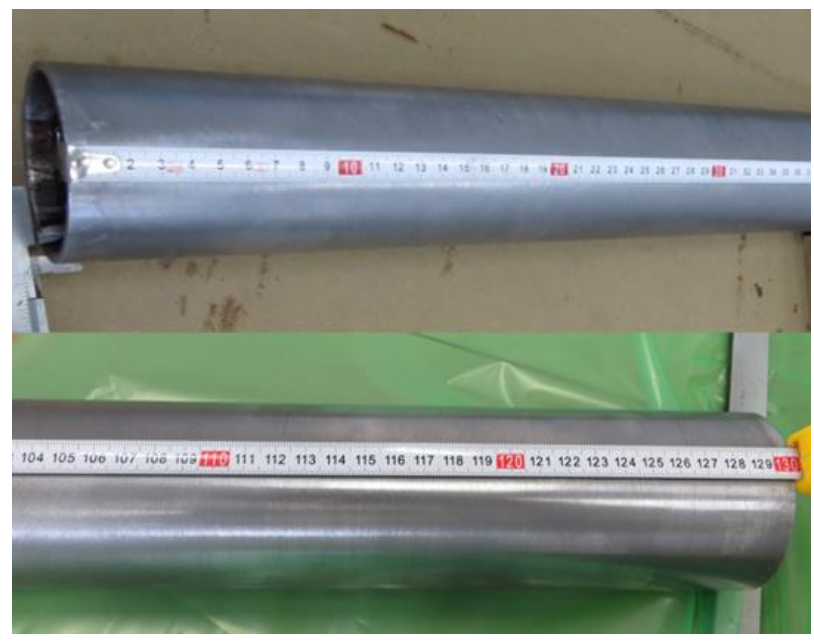

Figure 2 The steel mold with shine, $L=1300 \mathrm{~mm}, d=72$ $\mathrm{mm}, \mathrm{t}=4 \mathrm{~mm}$.

All samples resins and fillers mixing mechanical, later mixing during 15 minutes with Ultrasonic Cell Disirupter UCD650 for homogen mixtures in Figure 3.

Composite fiber fabric prepared by epoxy resin apply on carbon texture. Later, the carbon fabric wound six layer on mold by turning mechanism and applying resins hardener with nanofillers by brush in Figure 4.

After this step, the pipe put a package that no air leak. A vacuum system was take air from the package with composite pipe during one hour. Last step, the vacuum package with composite pipe were curing during 24 hours under vacuum in Figure 5.

So,one day later, the CRP pipe was take out package and mold. The CRP surfaces was smoothing by lathe and last step,it cuts in $30 \mathrm{~cm}$ parts for using in the impact experiments in Figure 6. 


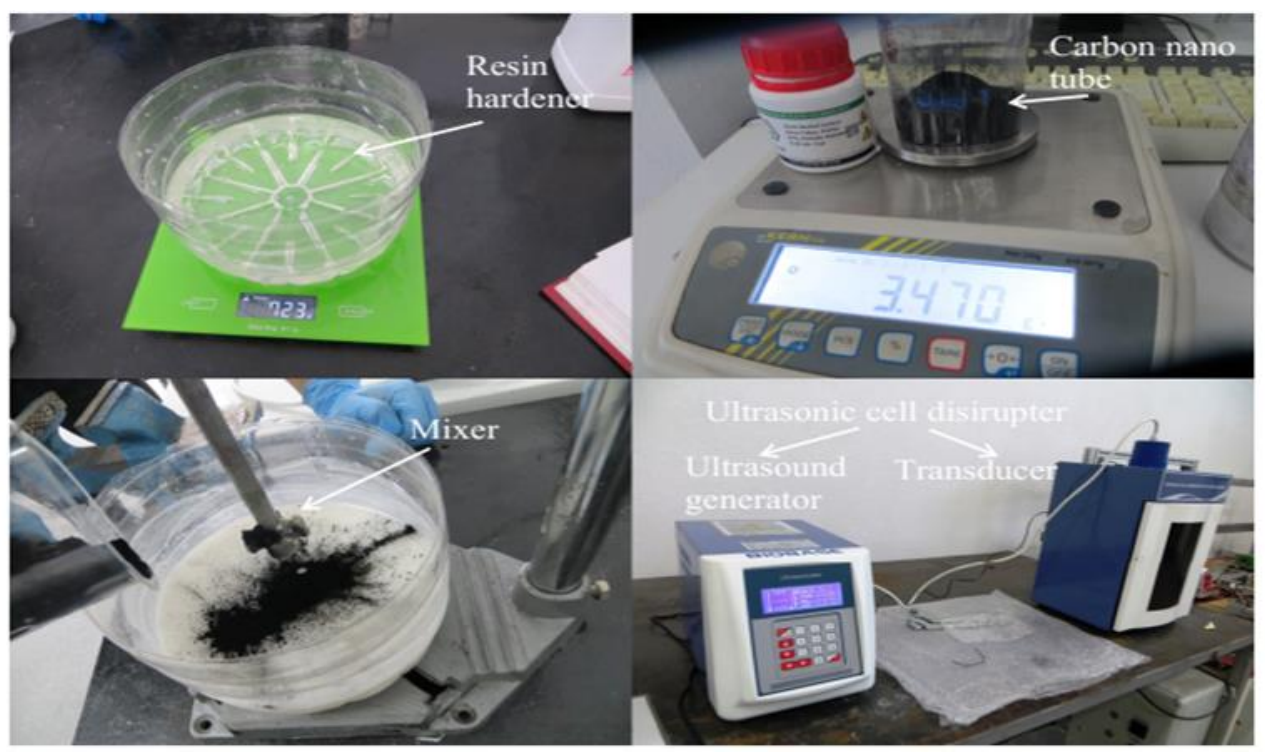

(a)

(b)

Figure 3 All resin hardener and CNT, nanoclay mixing mechanical (a), later by ultrasound (b).

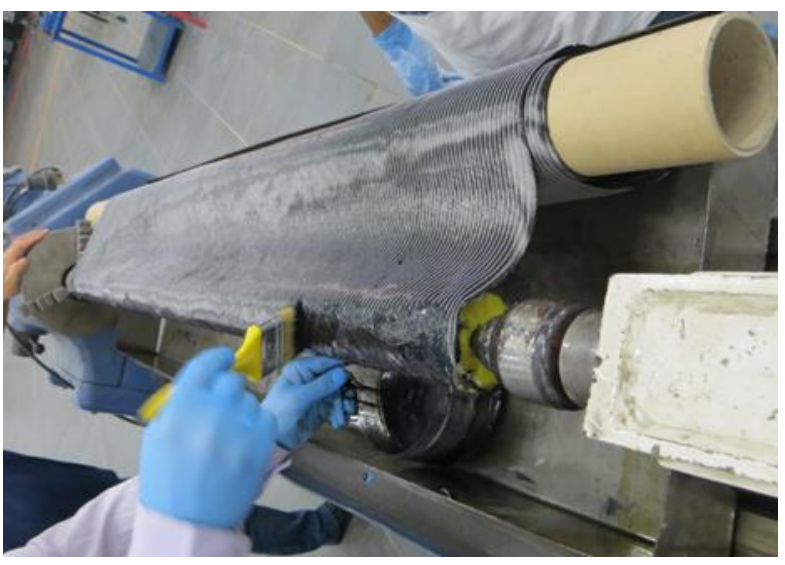

Figure 4 Fabrication composite pipe CRP to wound texture on the mold.

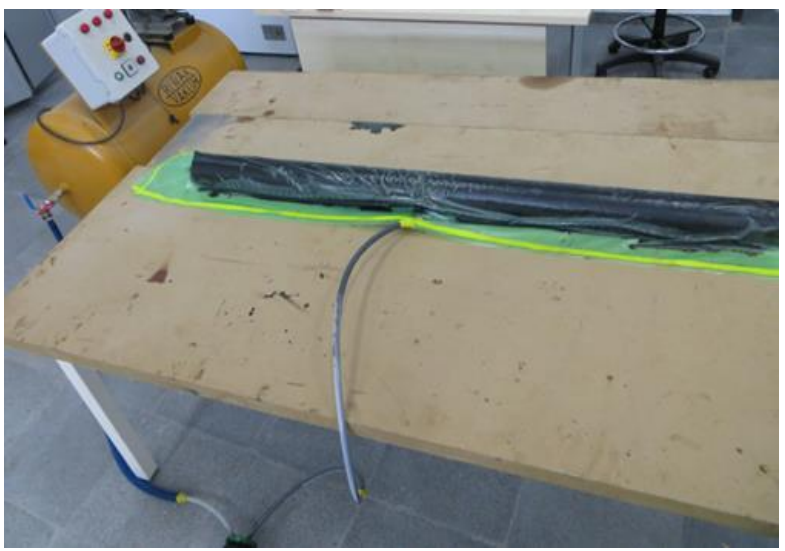

Figure 5 Vacuum process for CRP pipe after manufacture step.

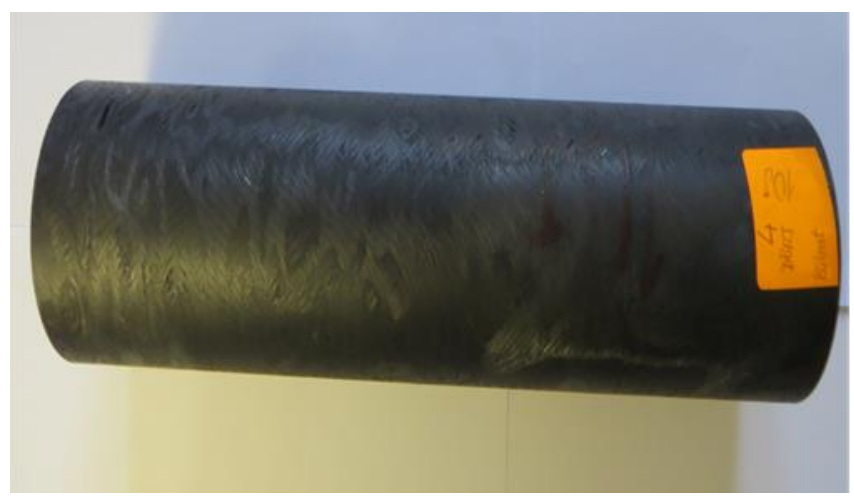

Figure 6 Composite pipe sample has $30 \mathrm{~cm}$ length.

\section{Results and Discussion}

\subsection{Results}

Determination of low velocity impact behavior of CRP pipes low-speed impact tests at different energy levels on test samples in Figure 7. Accordingly, impact tests were performed at low impact energies of $5 \mathrm{~J}, 10 \mathrm{~J}$ and $15 \mathrm{~J}$ carried out quickly. In order to obtain increased impact energy values, the striker height at which the mass will be deposited has been calculated theoretically. The striking was for $5 \mathrm{~J}$ energy level from a height of $0.9101 \mathrm{~m}$, and for energy level $10 \mathrm{~J}$ from a height of $0.182 \mathrm{~m}$. Last,it was dropped from a height of $0.273 \mathrm{~m}$ for energy level of $15 \mathrm{~J}$. A impact was made in the middle of each sample with a hemispherical striker. In order to correlate the damage mechanisms in the sample after impact with impact energy, the first repeated impact were prevented by holding the striker mass after making the blow with automatic mechanism. 


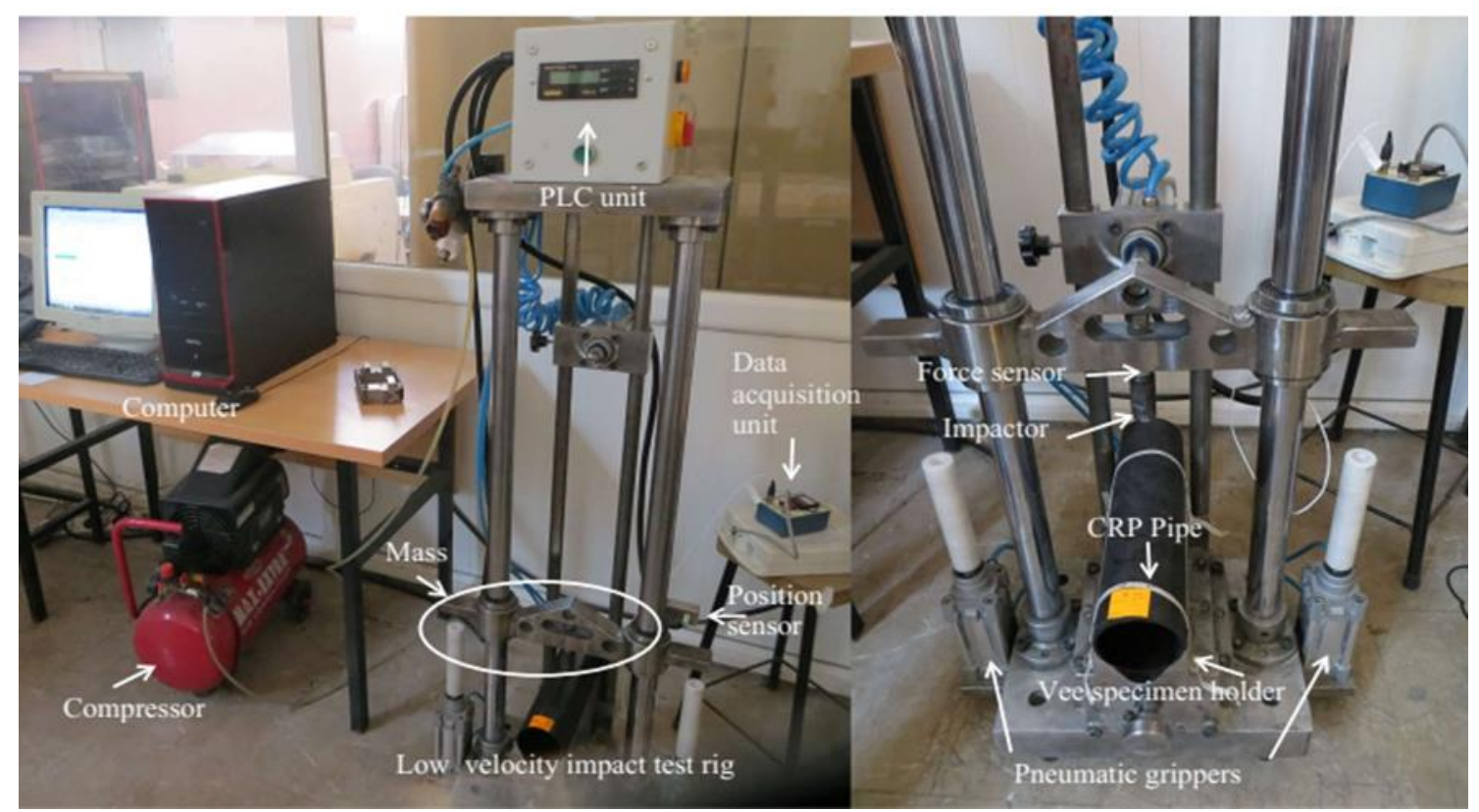

Figure 7 Low velocity impact test stand.

\subsubsection{Low Velocity Impact Testing}

Impact tests were carried out with a drop tower which has adjustable impactor height Figure 7. The impactor has a hemispherical shape (12 mm diameter, and $5.6 \mathrm{~kg}$ mass). The force variations have monitored by a sensor in millivolts scale. The impact tests were repeated 12 times at 5, 10 and 15 Joule (J) impact energy levels. Subsequently the signals have transmitted to the data acquisition card mounted in a PC.

Velocities of impacts were calculated from Kinetic Energy formula Equation (1).As a results calculations, impact velocities are $1.3363 \mathrm{~m} / \mathrm{s}$ for $5 \mathrm{~J}$ and $1.8898 \mathrm{~m} / \mathrm{s}$ for $10 \mathrm{~J}$ and $2.3145 \mathrm{~m} / \mathrm{s}$ for $15 \mathrm{~J}$.

$$
\Delta K . E .=\frac{1}{2} m v^{2}
$$

Fabricated composite pipes (CRP) testing mechanically based on ASTM D7136 / D7136 M-12, 2012, Standard Test Method Measurement Damage Fiber-Reinforced Polymer Matrix Composites Drop Weight Impact [32 - 42].

\subsubsection{Low Velocity Impact Testing Graphs}

The force versus time are shown in the graph of change and also contact force versus displacement. Energy-time and energyimpact energy and impact force-impact velocity and velocitytime and changes were obtained as a result of the kinetic analysis of the low-speed impact with a Excel Macro VBA computer program.

Contact force-time change curves obtained from low-speed impact experiments are one of the graphs used to determine the impact behavior of composite materials. In Figure 8a.,b.,c., and d., under increasing impact energy, the contact force with respect to time, graphs showing the change are given.

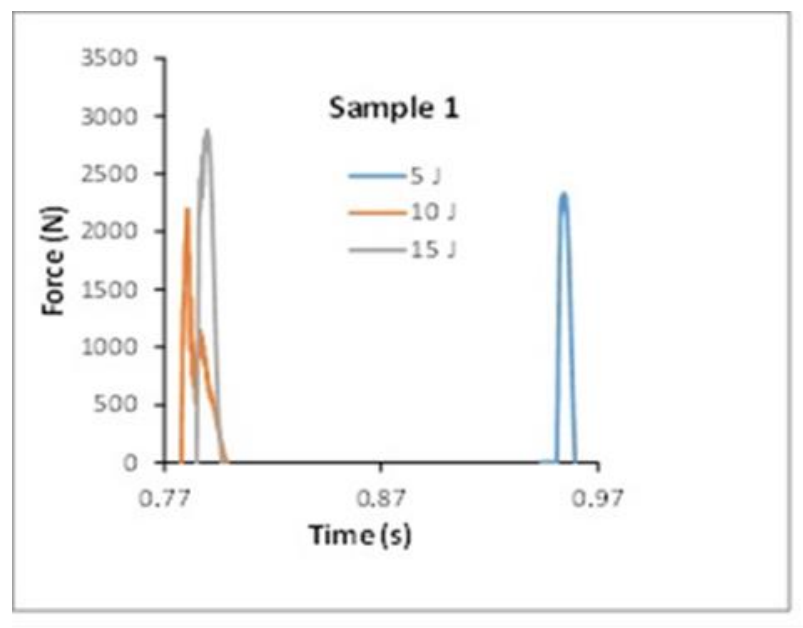

Figure 8a Force-Time graphs for Sample 1.

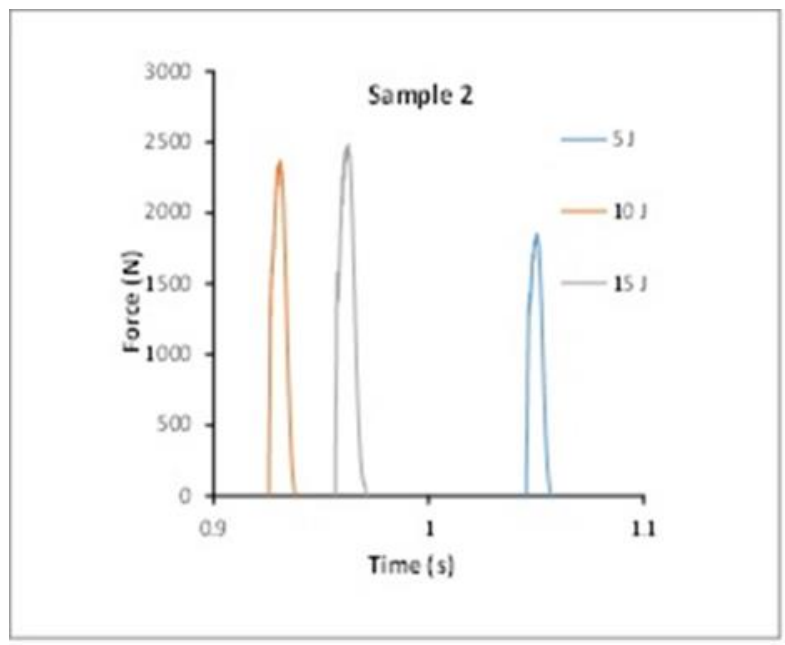

Figure $8 b$ Force -Time graphs for Sample 2. 


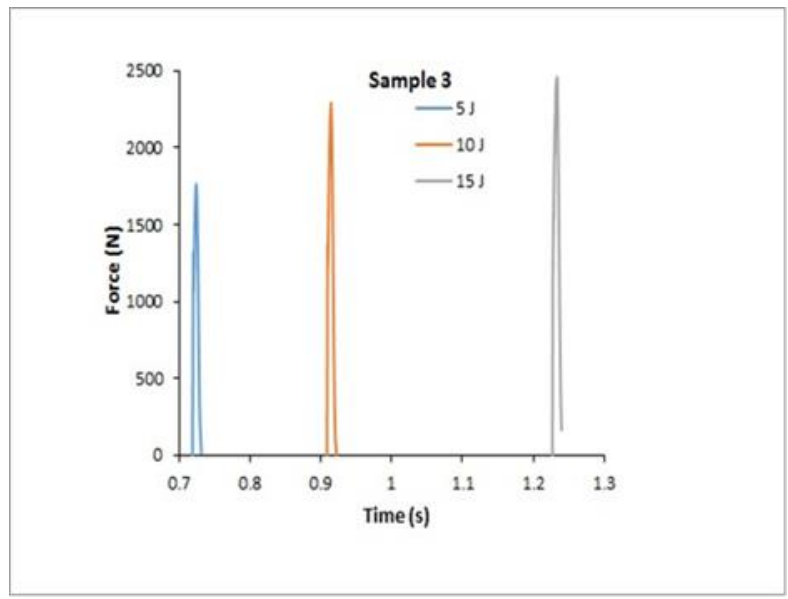

Figure 8c Force -Time graphs for Sample 3.

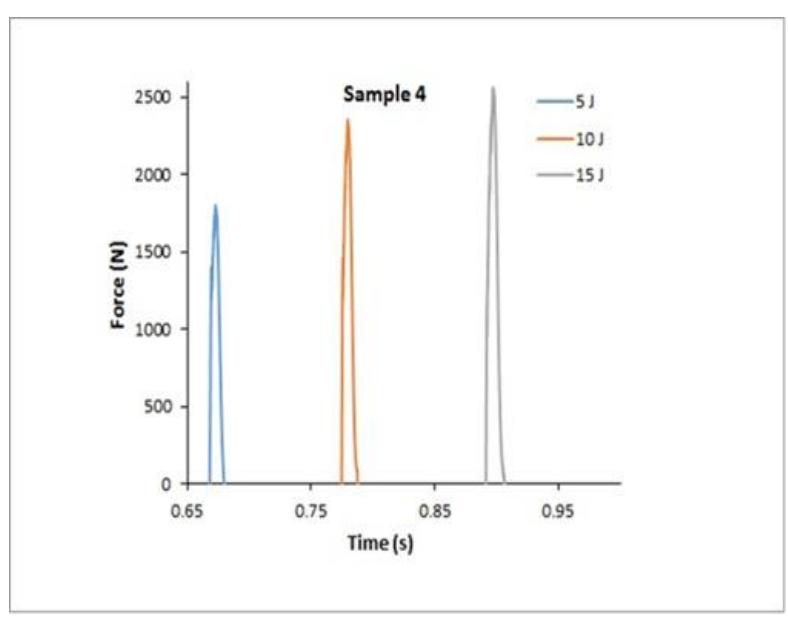

Figure 8d Force-Time graphs for Sample 4.

In Figure 9a. and 9b., shows force versus displacement for Sample 1 and 2 for all energy levels.

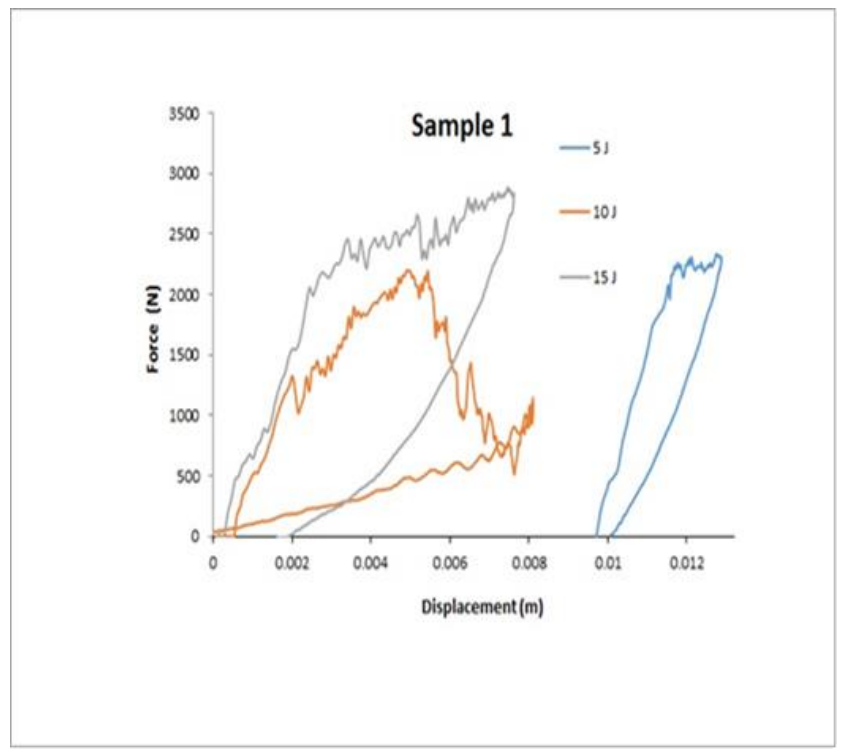

Figure 9a Force-Displacement graphs for Sample 1.

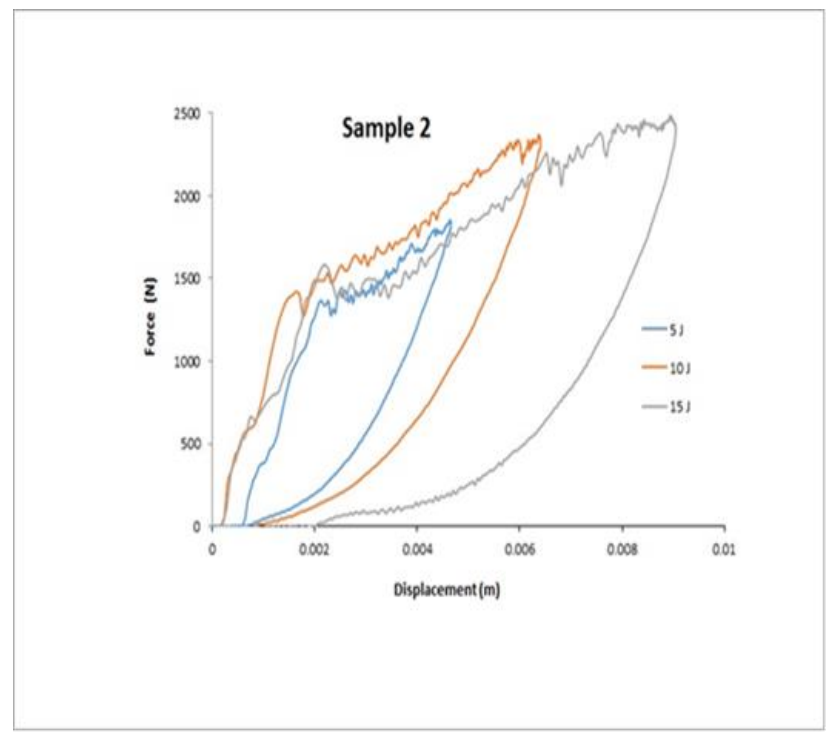

Figure $9 b$ Force-Displacement graphs for Sample 2.

In Figure 10a. and 10b., shows Energy - Impact Energy graphs for Samples 1 and 2 for all energy levels.

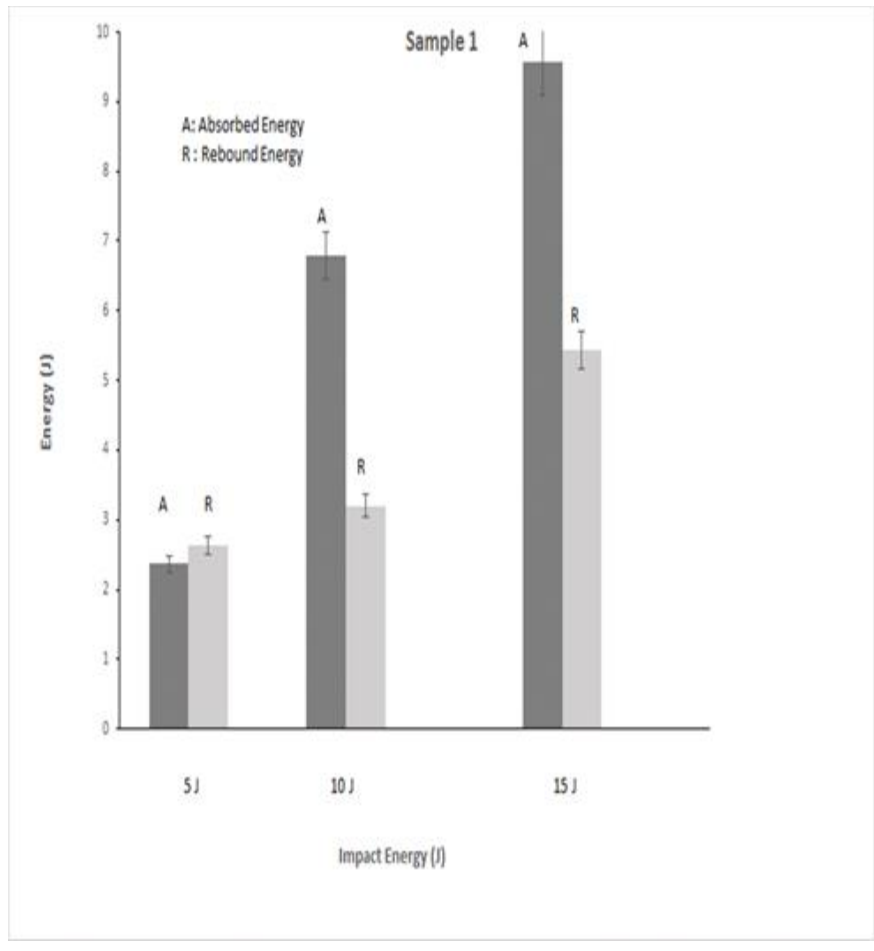

Figure 10a Energy - Impact Energy graphs for Samples 1. 


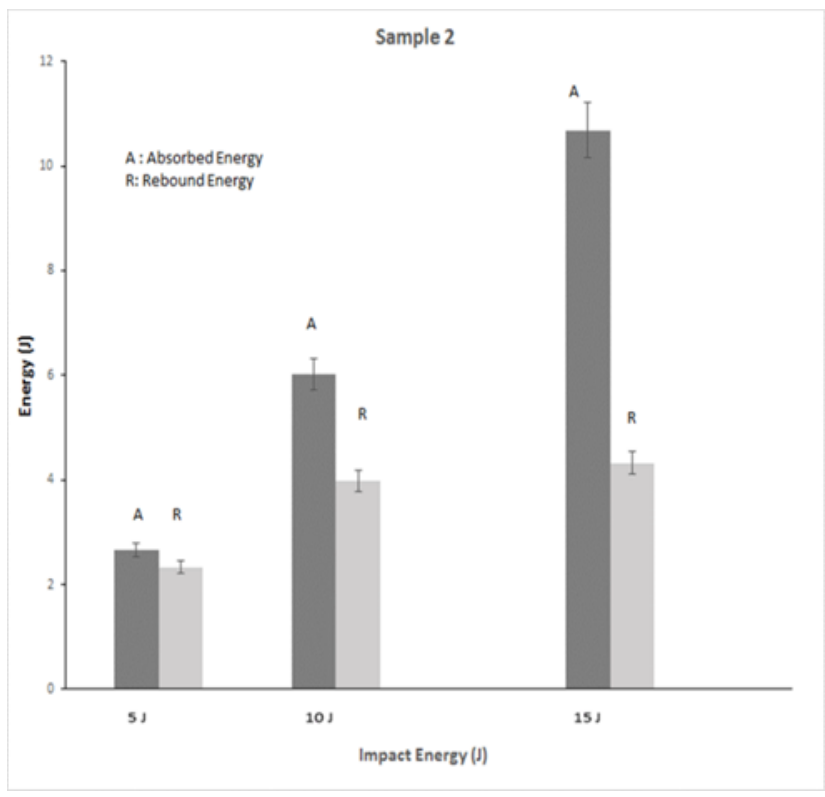

Figure 10b Energy - Impact Energy graphs for Samples 2.

And Table 1 is tabulating for Samples absorbed energy (\%) results versus energy levels.

Table 1. Samples absorbed energy (\%) results versus energy levels .

\begin{tabular}{|c|c|c|c|c|}
\hline $\begin{array}{c}\text { Energy } \\
\text { Level }\end{array}$ & $\begin{array}{c}\text { Sample 1 } \\
\text { Absorbed } \\
\text { Energy } \\
\%\end{array}$ & $\begin{array}{c}\text { Sample 2 } \\
\text { Absorbed } \\
\text { Energy } \\
\%\end{array}$ & $\begin{array}{c}\text { Sample 3 } \\
\text { Absorbed } \\
\text { Energy } \\
\%\end{array}$ & $\begin{array}{c}\text { Sample 4 } \\
\text { Absorbed } \\
\text { Energy } \\
\%\end{array}$ \\
\hline 5 J & 47.36 & 53.34 & 53.96 & 52.2 \\
\hline 10 J & 67.97 & 60.18 & 63.19 & 61.36 \\
\hline 15 J & 63.75 & 71.21 & 67.15 & 65.11 \\
\hline
\end{tabular}

\subsubsection{Damage Formation}

In the Figure 11, we see macro damage pictures for Sample 1 and 2 at $10 \mathrm{~J}$ energy levels.

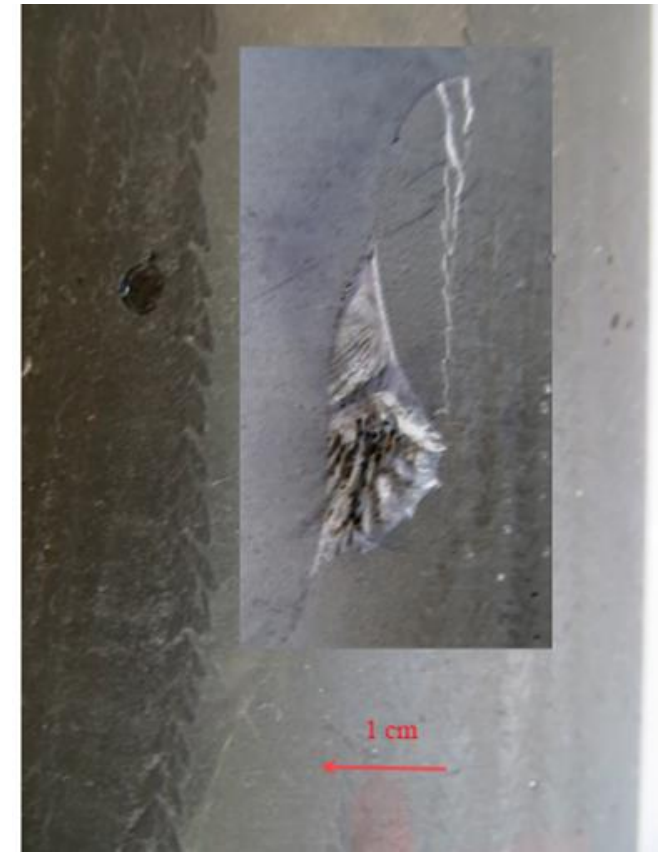

(a)

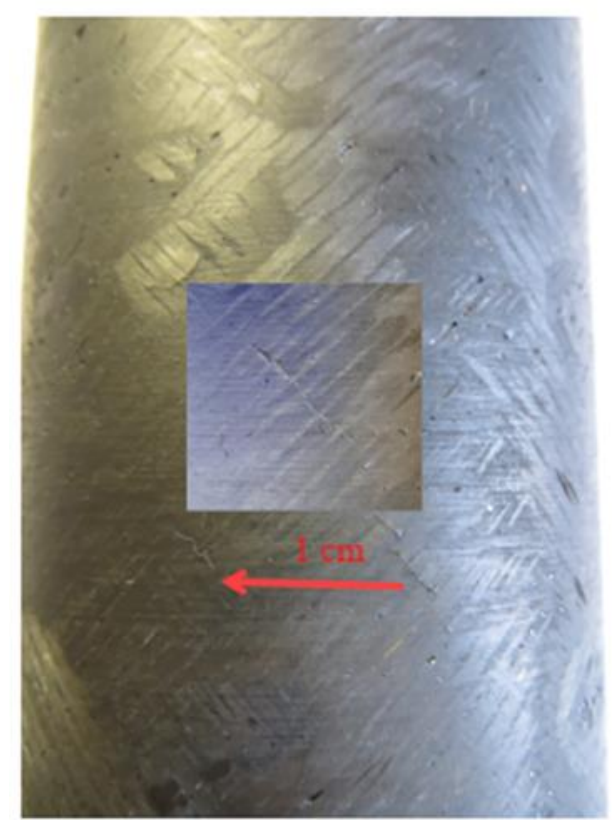

(b)

Figure 11 Damage pictures in macro scale: (a) Sample 1 at $10 \mathrm{~J}$ and (b) Sample 2 at $10 \mathrm{~J}$.

\subsection{Discussion}

In Figure 8a.,b.,c., and d., it is view that the contact force-time changes obtained at the impact energies of $5 \mathrm{~J}, 10 \mathrm{~J}$ and $15 \mathrm{~J}$ are in the form of a rattle curve. Each curved load has an increase in the maximum force achieved value and also a reduction portion in unloading. All graphs were formed by the striker rebounding from the sample surface after contact with the sample. That is, most of the applied impact energy was absorbed by the sample. The rest of the energy absorbed was used to rebound the striker. 
The slope in the increasing part of the force-displacement curve is called the bending stiffness due to the resistance of the specimen against the impact load (Fig.9a. and b.). Oscillations and changes in bending stiffness show the damage in the sample. There are serious changes in bending stiffness of composite CRP pipes, which are exposed to low-speed impact at different energy levels. As seen Figure 9a. and 9b., adding nanofiller like Sample 2 , displacements seriously reduces all energy levels.For $5 \mathrm{~J}$ energy level, displacement reduces $0.012 \mathrm{~m}$ to $0.004 \mathrm{~m}$, and at $10 \mathrm{~J}$ level, reduces $0.008 \mathrm{~m}$ to $0.0062 \mathrm{~m}$. The area under the force-displacement graph gives the work done on the sample (the energy absorbed in the sample). As the impact energy increases, the area under the force-displacement curve increases, and accordingly, the sample is deflected.It is clearly seen in Figure 9a. and 9b. that the amount of absorbed energy has also increased.

In Figure 10a. and 10b. and Table 1 cleary shows that at $5 \mathrm{~J}$ energy level, Sample 1 absorbed $2.368 \mathrm{~J}$ and Sample 2 absorbed $2.667 \mathrm{~J}$, less than $12.62 \%$ from sample 2. Sample 1 absorbed $6.797 \mathrm{~J}$ and Sample 2 absorbed $6.018 \mathrm{~J}$ at $10 \mathrm{~J}$ energy level, more than $7.79 \%$ from Sample 2 . Last level, Sample 1 absorbed $9.563 \mathrm{~J}$ and Sample 2 absorbed $10.68 \mathrm{~J}$, less than 7.46 $\%$ from Sample 2 at $15 \mathrm{~J}$ level. Adding nanofiller effect positively direction of composite pipes absorbed energy. If rebound energy increasing, composite pipes have crack and delamination on surfaces in Figure 11.

In the Figure 11, we see that adding nanofiller increase CRP pipe strength to damage. Sample 1 hasn't nanofillers and easily cracking and delamination at $10 \mathrm{~J}$ in Figure 11a. On the contrary, sample 2 has nanofiller and it has only major cracks in Figure 11b. The macro damage photo shows increase strength with adding equal mass percent multiwall carbon nano tube and nanoclay. In Figure 11a., big part take out from Sample 1 at impact point and longitudinal cracks occur. And in Figure 11b., Sample 2 surface shows major crack occur at impact point but no longitudinal cracks.

\section{Conclusions and Recommendations}

This work has very different specifications than fiber winding composite pipe. The composite pipes produces by carbon fiber fabric wound include resin with two nanofillers and testing four samples at three different energy levels.Carbon fabric composite pipe wound is fast, economic manufacture than fiber winding composite pipe [32] .Because, there are no prepreg and autoclave process in our hand lay-up method. In this study, displacements seriously reduces all energy levels when adding nanofiller like Sample 2 which at $5 \mathrm{~J}$ energy level, displacement reduces $0.012 \mathrm{~m}$ to $0.004 \mathrm{~m}$, and at $10 \mathrm{~J}$ level, reduces $0.008 \mathrm{~m}$ to $0.0062 \mathrm{~m}$. We see that, at $5 \mathrm{~J}$ energy level, Sample 1 absorbed $2.368 \mathrm{~J}$ and Sample 2 absorbed $2.667 \mathrm{~J}$,more than $12.62 \%$ (Figure 10). It has been determined at $15 \mathrm{~J}$ impact energy that $63.75 \%$ of the total energy for Sample 1, and $71.21 \%$ of the total energy for Sample 2 and $67.15 \%$ of the total energy for Sample 3, and $65.11 \%$ of the total energy for Sample 4 are absorbed by the samples (Table 1). Energy back the remainder was spent on the striker's rebound from the sample.

As a result, nanofillers, nanoclay and carbon nanotube, contents have very effective on the CRP structure which increase absorbed energy level more than $7.46 \%$ with nanofiller Sample 2 compared to non-nanofiller Sample 1 at $15 \mathrm{~J}$ energy level.The content level of nanofiller must be equal mass like Sample 2. So, nanofillers reduces damage CRP pipes, effectively. Therefore, we compare differences fabric wound composite pipe with nanofillers to fiber winding composite pipe mechanical properties [32].

\section{Acknowledge}

This study was supported by the Coordinatorship of Scientific Research Projects at Necmettin Erbakan University with the project number 181431003 .

\section{References}

[1] Henderson L.,2019. Carbon Fibers and Their Composite Materials.MDPI.

[2] Al-Samman T.,2019. Material and Process Design for Lightweight Structures.MDPI.

[3] Marshall I. H.,1999. Composite Structures, 10th. International Conference.Elsevier.47.

[4] Burchell T. D., ed.,1999. Carbon Materials for Advanced Technologies.Elsevier.

[5] Fitzer E.,1998. Reinforcements and Carbon Carbon Composites.Springer.

[6] Bunsell A. R.,2005. Fundamentals of Fibre Rein- forced Composite Materials.IOP.

[7] Advani S. G.,1992. Computer Aided Design in Composite Material Technology III.Elsevier.

[8] Campbell F. C. Jr.,2004. Manufacturing Process-es for Advanced Composites. Elsevier.

[9] Burchell T. D., ed.,1999. Carbon Materials for Advanced Technologies.Elsevier.

[10] Bai J.,2013. Advanced Fibre-Reinforced Poly-

mer (FRP) Composites for structural applications. Elsevier.

[11] Aliabadi M. H.,2015. Woven Composites. Impe- rial College Press.

[12] Kompis V.,2008. Composites with Micro and NanoStructure Computational Modeling and Experiments. Springer.

[13] Suzuki S., ed.,2013. Syntheses and Applica- tions of Carbon Nanotubes and Their Composites. Intech.

[14] Loos M.,2015. Carbon Nanotube Reinforced Composites. CNR Polymer Science and Technology. Elsevier.

[15] Islam M.,2015. Characterization Carbon Fiber Reinforced Epoxy Composites Modified Nanoclay Carbon Nanotubes. Procedia Engineering. 105:821-828.

[16] Vaka M.,2021. Carbon Nanotubes and Their Composites From Synthesis to Applications.Contem- porary Nanomaterials.

[17] Yuan P., Bergaya F., eds.,2016. Nanosized Tubular Clay Minerals Halloysite- Imogolite.Elsevier.

[18] Jawaid M.,2016. Nanoclay Reinforced Polymer Composites Natural Fibre Nanoclay Hybrid Composites. Springer.

[19] Hashin Z., Herakovich C. T.,1983. Mechanics of Composite Materials. Recent Advances. Pergamon.

[20] Hinton M. J.,2001. Failure Criteria in Fibre-ReinforcedPolymer Composites.Elsevier.

[21] Voyiadjis G. Z.,1998. Damage Mechanics in Engineering Materials.Elsevier.

[22] Talreja R.,2012. Damage and Failure of Com- posite Materials.Cambridge.

[23] Talreja R.,2016. Modeling Damage, Fatigue and Failure of Composite Materials.Woodhead Publishing. 
[24] Jones N.,1993. Structural Crashworthiness and Failure.Elsevier.

[25] Fink J. K.,2014. High Performance Polymers. 2nd. ed. Elsevier.

[26] Daniel I. M.,1994. Engineering Mechanics of Composite Materials.Oxford.

[27] Daniel I. M,2006. Engineering Mechanics of Composite Materials. 2nd. ed.Oxford.

[28] Herakovich C. T.,1998. Mechanics of Fibrous Composites.Wiley.

[29] Datoo M.,1991. Mechanics of Fibrous Compo- sites. Springer.

[30] Vautrin A.,Sol H ,ed.,1991. Mechanical Identi-fication of Composites .Springer.

[31] Mishnaevsky L. L.,2007. Computational Meso- mechanics of Composites Numerical Analysis Microstructures Strength Damage Resistance.Wiley.

[32] Kara M.,2012. Failure Behavior of Filament Wound GRP Pipes Under Internal Pressure Repaired With Patch After Low Velocity Impact.Ph.D. Thesis. Selcuk University, Graduate School of Natural and Applied Sciences, Department of Mechanical Engi- neering.

[33] Ji C.,2007. Impact Damage of 3D Orthogonal Woven Composite. Applied Composite Materials. Springer.14:343362.

[34] Shi Y. ,2017. Modelling low velocity impact induced damage in composite laminates.Mechanics of Advanced Materials and Modern Processes.3;14:1-12.

[35] François D., eds.,2002. From Charpy To Present Impact Testing.Elsevier.

[36] Baucom J.,2005. Low-velocity impact damage progression in woven E-glass composite systems. Composites Part A. Elseiver.36:658-664.

[37] ASTM D7136 / D7136 M-12, 2012. Standard Test Method Measurement Damage Fiber-Reinforced Polymer Matrix Composites Drop Weight Impact. ASTM.

[38] Abobo I. D.,2021. Effect of organoclay rein-forcement on the mechanical and thermal properties of unsaturated polyester resin composites. Epitoanyag -Journal of Silicate Based and Composite Materi- als.2;73:63-67.

[39] Islam, F.,2019. Mechanical and Interfacial Characterization of Jute Fabrics Reinforced Unsaturated Polyester Resin Composites. Nano Hybrids and Composites.25:22-31.

[40] Kiani M., Parvaneh V., et al.,2020. Fabrication and investigation of the mechanical properties of $\mathrm{PVC} /$ carbon fiber/graphene nano- composite pipes for oil and gas applications. Journal of Thermoplastic Composite Materials.1-16.

[41] Jemii H., et al.,2017. Mechanical, thermal and physicochemical behavior of virgin and hydro-thermally aged polymeric pipes. Journal of Thermo-plastic Composite Materials.1-21. 